\title{
Pre-existing systemic inflammation attenuates bacterial clearance by the liver in porcine abdominal sepsis
}

\author{
K Hanslin ${ }^{1 *}$, J Sjölin ${ }^{1}$, P Skorup ${ }^{1}$, F Wilske ${ }^{1}$, R Frithiof ${ }^{2}$, A Larsson ${ }^{3}$, M Castegren ${ }^{1}$, M Lipcsey ${ }^{2}$ \\ From ESICM LIVES 2015 \\ Berlin, Germany. 3-7 October 2015
}

\section{Introduction}

Bacterial translocation from the gut has been suggested to induce and maintain the systemic inflammatory response (SIRS) and organ dysfunction. The reticuloendothelial system in the liver has a pivotal role in clearing the blood from circulating bacteria. To date, the effects of SIRS on hepatic bacterial clearance are not fully understood.

\section{Objectives}

To investigate if pre-existing inflammation, as seen in sepsis, influences the trans-hepatic bacterial clearance.

\section{Methods}

The study was conducted on anesthetized pigs in an intensive care setting. All animals were subjected to an infusion of $E$ coli in the portal vein for 3 hours. In Group $1(\mathrm{n}=6)$, a systemic inflammatory response was induced by a continuous intravenous endotoxin infusion starting $24 \mathrm{~h}$ prior to the bacterial infusion. Group 2 $(n=6)$ received the bacterial infusion without prior endotoxin exposure. Three animals (Group 3), serving as controls for effects of $24 \mathrm{~h}$ anesthesia, received saline instead of endotoxin for $24 \mathrm{~h}$ prior to the bacterial infusion. Bacterial counts in the portal and hepatic vein, as well as the levels of tumor necrosis factor- $\alpha$ (TNF- $\alpha$ ) in venous blood were analyzed hourly during the bacterial infusion.

\section{Results}

All animals subjected to endotoxin developed SIRS. The amounts of bacteria administered were comparable

${ }^{1}$ Uppsala University, Section of Infectious Diseases, Department of Medical Sciences, Uppsala, Sweden

Full list of author information is available at the end of the article between the groups. The ratio of hepatic to portal vein bacterial counts was higher in Group 1 vs. 2 ( $\mathrm{p}<0.001$; Figure 1). Peak plasma levels of TNF- $\alpha$ in Group 1 (1957 pg/mL (1843-2092) median (IQR)) were lower compared to Group 2 (69200 pg/mL (60305-77350); p < $0.001)$. Group 3 was numerically intermediate in bacterial counts and TNF- $\alpha$ levels and, according to the predefined plan, not included in the primary analysis.

\section{Conclusions}

Our results suggest that despite lower inflammatory response to bacterial infusion, the trans-hepatic bacterial clearance is a magnitude lower in pigs with pre-existing systemic inflammatory response. Should similar mechanisms operate in human critical illness, then hepatic clearance of bacteria from the gut is impaired by SIRS.

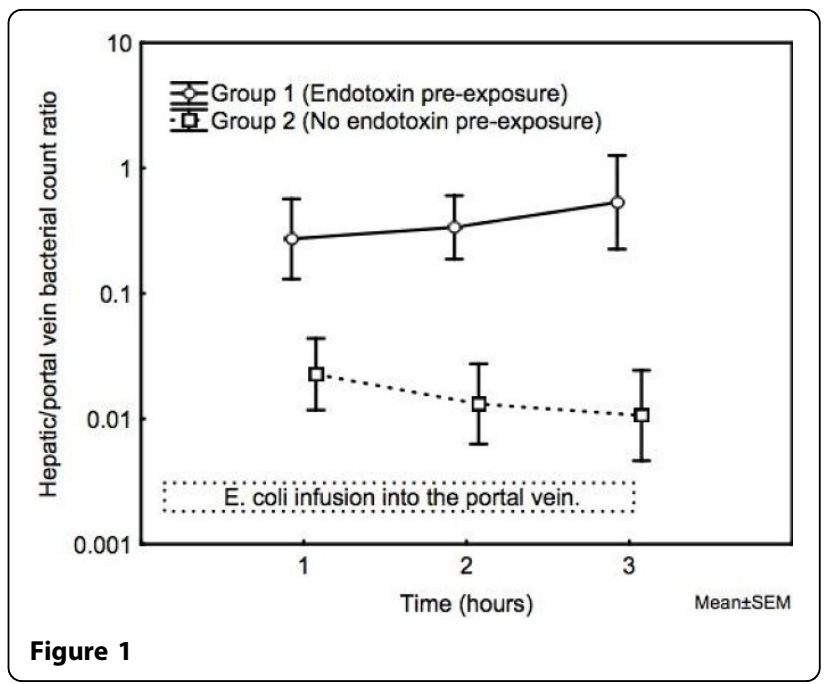




\section{Authors' details}

${ }^{1}$ Uppsala University, Section of Infectious Diseases, Department of Medical Sciences, Uppsala, Sweden. ${ }^{2}$ Uppsala University, Section of Anesthesiology and Intensive Care, Department of Surgical Sciences, Uppsala, Sweden.

${ }^{3}$ Uppsala University, Section of Clinical Chemistry, Department of Medical

Sciences, Uppsala, Sweden.

Published: 1 October 2015

doi:10.1186/2197-425X-3-S1-A620

Cite this article as: Hanslin et al:: Pre-existing systemic inflammation

attenuates bacterial clearance by the liver in porcine abdominal sepsis.

Intensive Care Medicine Experimental 2015 3(Suppl 1):A620.

\section{Submit your manuscript to a SpringerOpen ${ }^{\circ}$ journal and benefit from:}

- Convenient online submission

- Rigorous peer review

- Immediate publication on acceptance

- Open access: articles freely available online

- High visibility within the field

- Retaining the copyright to your article

Submit your next manuscript at $\gg$ springeropen.com 